\title{
FAKTOR-FAKTOR YANG MEMPENGARUHI NIAT INDIVIDU MELAKUKAN WHISTLEBLOWING: STUDI ANALISIS META
}

\author{
Fransiska Alicia \\ Program Studi Akuntansi, Fakultas Bisnis, Universitas Kristen Duta Wacana \\ Email: fransiscaalicia@gmail.com
}

\begin{abstract}
This study aims to determine the factors that influence individual intention to do whistleblowing using 10 years of research data. The purpose of this research is to examine the association between Ethical Judgement Whistleblowing, Locus of Control, Organizational Commitment, Fraud Severity Rate, Personal Cost Reporting, Personal Responsibility Reporting, Job Satisfaction, Fair Treatment, Cooperativeness, Moral Reasoning, Anonym Reporting Channels, Education on Whistleblowing, Attitude, Perceived Behavioral Control, Organizational Support, Subjective Norms, Professional Commitment, Ethical Climate-Egoism, Ethical Climate-Benevolence, Ethical Climate-Principle, Anticipatory Socialization, Self-Interest, Feel Anger, Ethnic, Self-Efficacy, Managerial Status, Ethical Decision Making, Reward, Corporate Ethical, Gender, Controllability to whistleblowing intention. This research accumulates and integrates existing studies using meta-analysis techniques on 35 sample journals published between 2010-2020. Based on the research results, there are 28 variables as factors that can influence whistleblowing intention.
\end{abstract}

Keywords: whistleblowing, whistleblowing intention, factors affecting whistleblowing, meta-analysis

\begin{abstract}
ABSTRAK
Penelitian bertujuan untuk mengetahui faktor-faktor yang mempengaruhi niat individu melakukan whistleblowing dengan menggunakan 10 tahun data penelitian. Penelitian ini menguji pengaruh Ethical Judgement Whistleblowing, Locus of Control, Organizational Commitment, Fraud Severity Rate, Personal Cost Reporting, Personal Responsibility Reporting, Job Satisfaction, Fair Treatment, Cooperativeness, Moral Reasoning, Anonym Reporting Channels, Education on Whistleblowing, Attitude, Perceived Behavioral Control, Organizational Support, Subjective Norms, Professional Commitment, Ethical Climate-Egoism, Ethical Climate-Benevolence, Ethical Climate-Principle, Sosialisasi Antisipatif, Self-Interest, Feel Anger, Suku Bangsa, Self-Efficacy, Managerial Status, Ethical Decision Making, Reward, Corporate Ethical, Jenis Kelamin, Controllability terhadap niat whistleblowing. Penelitian ini mengakumulasi dan mengintegrasikan studi yang telah ada dengan menggunakan teknik meta analisis terhadap 35 jurnal sampel yang dipublikasikan antara tahun 20102020. Berdasarkan hasil penelitian, terdapat 28 variabel sebagai faktor yang dapat mempengaruhi niat whistleblowing.
\end{abstract}

Kata kunci: pengaduan, niat pengaduan, faktor yang mempengaruhi pengaduan, meta analisis 


\section{PENDAHULUAN}

Insiden kecurangan organisasi semakin menyita perhatian dunia misalnya kasus Enron, WorldCom, Anderson, dan Tyco. Di Indonesia juga terjadi kasus kecurangan yang sangat menggemparkan yaitu kasus korupsi e-KTP yang terjadi pada tahun 2015 namun hingga saat ini masih terus diperbincangkan. Hal ini disebabkan kasus korupsi tersebut melibatkan pihak swasta, legislatif, bahkan eksekutif. Selain itu, kerugian negara akibat kasus e-KTP mencapai 2,3 triliun. Menurut ICW, pada tahun 2019 tercatat ada 271 kasus korupsi yang ditangani oleh Kejaksaan Agung, Kepolisian dan Komisi Pemberantasan Korupsi (KPK) dengan jumlah tersangka 580 orang, kerugian negara 8,4 triliun, jumlah suap Rp 200 miliar, pungutan liar 3,7 miliar dan jumlah pencucian uang 108 miliar. Kecurangan yang terjadi akan mengakibatkan kerugian yang sangat besar, sehingga diperlukan upaya untuk meminimalisir potensi terjadinya kecurangan. Salah satu upaya untuk meminimalisir kecurangan adalah dengan melakukan pencegahan kecurangan. Pencegahan terhadap kecurangan dianggap sebagai sebuah solusi untuk menangkal pelaku potensial, mempersempit ruang gerak dan mengidentifikasi kegiatan yang berisiko.

Kasus kecurangan cenderung dapat diungkap karena adanya pengaduan (whistleblowing). Melakukan pengaduan ke atasan disebut sebagai internal whistleblowing, sedangkan melakukan pengaduan kepada masyarakat atau pihak eksternal organisasi disebut sebagai eksternal whistleblowing. Pihak yang melaporkan adanya dugaan kecurangan, penyalahgunaan wewenang, atau ketidakpatuhan secara hukum maupun kode etik biasa disebut whistleblower. Setiap orang bisa menjadi whistleblower, namun untuk menjadi seorang whistleblower dibutuhkan keberanian dan keyakinan untuk melakukannya. Fakta dari penelitian yang dilakukan IBE bahwa 1 dari 4 pegawai yang sadar akan adanya kecurangan di tempat kerja, hanya separuhnya yang berani melaporkannya, sisanya memilih untuk diam dan tidak melaporkannya (Purba, 2015 dalam Gaurina et al, 2017). Seseorang yang berada dalam sebuah organisasi atau instansi umumnya akan menghadapai dilema etis dalam memutuskan apakah harus mengungkapkan atau membiarkannya. Di satu sisi sebagian orang mungkin memandang whistleblower sebagai penghianat organisasi karena telah mengungkap rahasia organisasi, di sisi lainnya sebagian orang memandang whistleblower sebagai pelindung yang menjunjung tinggi nilai-nilai moral yang dianggap lebih penting dari loyalitas kepada organisasi.

Kasus kecurangan cenderung sulit terungkap atau terdeteksi karena akan dipersiapkan atau disusun secara sistematis. Namun, biasanya anggota di dalam organisasi misalnya karyawan, anggota dewan atau auditor internal, cenderung mengetahui kecurangan yang dilakukan oleh organisasinya sendiri. Tjahjono et al (2013) dalam Gaurina et al (2017) juga menyatakan bahwa pegawai merupakan pihak yang paling tahu mengenai terjadinya kecurangan (fraud) di dalam perusahaan. Meskipun demikian, tidak banyak individu yang berani mengungkapkan kecurangan tersebut. Sikap tidak berani ini dapat disebabkan oleh beberapa faktor seperti mutasi jabatan, pemecatan, pengucilan bahkan sampai pengancaman. Sebagai contoh seperti kasus Novel Baswedan, yaitu seorang penyidik KPK yang disiram air keras di dekat rumahnya. Salah satu dugaan Novel Baswedan di siram air keras terkait dengan kasus e-KTP. Peran whistleblower sangatlah penting dalam mengungkap suatu tindakan melawan hukum di dalam internal organisasi. Namun, banyak orang yang takut untuk melaporkan tindak kecurangan, karena tak sedikit risiko yang harus dihadapi, bahkan sulit dihindari dan solusinya mereka lebih memilih untuk diam.

$$
\text { Para pembuat kebijakan telah }
$$
menciptakan peraturan-peraturan yang membuat pegawai akan lebih terdorong atau termotivasi untuk melakukan tindakan whistleblowing. Di Amerika Serikat untuk mendorong niat whistleblowing diterbitkan Sarbanes Oxley Act of 2002 (SOX) yang mewajibkan perusahaan go public untuk mengembangkan sistem whistleblowing yang merupakan bagian dari sistem pengendalian internal (Brennan dan Kelly, 2007). Sarbanes Oxley Act of 2002, Section 301 dan 806, dirancang secara khusus untuk mendorong whistleblowing dan menyediakan perlindungan dari retaliasi bagi karyawan yang mengungkapkan hal-hal yang tidak jelas atas masalah akuntansi dan audit. Di Indonesia regulasi mengenai whistleblowing tercantum dalam Undang-Undang Nomor 13 Tahun 2006 
tentang Perlindungan Saksi dan Korban serta Surat Edaran Mahkamah Agung Nomor 4 Tahun 2011 tentang Perlakuan terhadap Pelapor Tindak Pidana dan Saksi Pelaku yang Bekerja Sama. Meskipun demikian regulasi tersebut tidak cukup untuk membuat organisasi meningkatkan partisipasi individu dalam melaporkan kecurangan. Selain itu juga pelapor atau whistleblower bisa dengan sangat mudah berubah statusnya menjadi tersangka atas pencemaran nama baik.

Oleh karena itu, dibutuhkan analisis terhadap faktor-faktor yang mempengaruhi niat individu melakukan whistleblowing. Memahami faktor-faktor tersebut penting dilakukan agar organisasi dapat membuat kebijakan dan sistem whistleblowing yang paling efektif. Terdapat begitu banyak penelitian terkait faktor-faktor yang mempengaruhi niat individu melakukan whistleblowing, dengan latar belakang, rumusan masalah dan pengukuran variabel yang berbeda-beda, namun setiap pengukuran variabel tersebut belum tentu teruji validitasnya. Banyaknya penelitian serupa tentunya sulit bagi pengguna untuk memutuskan penelitian yang akan digunakan sebagai acuan karena memiliki hasil yang berbeda-beda. Oleh karena itu, diperlukan koreksi terhadap ketidaksempurnaan penelitian atau artefak. Koreksi tersebut dapat dilakukan dengan menggunakan analisis meta yaitu analisis statistik yang menggabungkan hasil berbagai studi ilmiah.

Berdasarkan penelusuran dari berbagai sumber, penelitian analisis meta whistleblowing belum pernah dilakukan sebelumnya. Oleh karena itu, penelitian ini akan sangat bermanfaat karena akan dilakukan pengkajian ulang dari penelitian-penelitian terdahulu dengan menggunakan analisis meta, untuk mengurangi subjektivitas dari berbagai penelitian sehingga membantu pihak yang membutuhkan untuk memecahkan masalah.

Pentingnya dilakukan analisis meta terkait faktor-faktor yang mempengaruhi niat individu melakukan whistleblowing adalah memberikan kesimpulan yang jelas dan tepat serta untuk memandu penelitian di masa depan dalam memilih pengukuran yang valid dari banyaknya penelitian terdahulu tentang whistleblowing. Penelitian ini bertujuan untuk menguji faktor-faktor apa saja yang mempengaruhi niat individu melakukan whistleblowing dengan menggunakan metode analisis meta.

\section{KAJIAN LITERATUR}

\section{Teori Perilaku Terencana (Theory of Planned Behavior)}

Teori Perilaku Terencana (Theory of Planned Behavior/ TPB) merupakan teori dalam ilmu psikologi yang menghubungkan antara keyakinan dan perilaku. TPB menyatakan bahwa sikap yang mengarah pada tingkah laku (attitude towards behavior), norma subjektif (subjective norm), dan persepsi kontrol perilaku (perceived behavioral control) membentuk sebuah intensi pada perilaku individu sebagai dasar untuk berperilaku (Ajzen, 1991). Tingkatan relatif dari ketiga determinan tersebut dapat berbeda-beda dalam berbagai perilaku dan situasi sehingga dalam pengaplikasiannya mungkin ditemukan bahwa hanya sikap yang berpengaruh pada minat, pada kondisi lain sikap dan persepsi kontrol perilaku cukup untuk menjelaskan minat, atau bahkan ketiga-tiganya berpengaruh.

Tindakan whistleblowing merupakan perilaku yang direncanakan oleh whistleblower. Tindakan whistleblowing tergantung pada niat pelapor kecurangan atau whistleblower apakah akan memutuskan untuk melakukan whistleblowing atau tidak. Theory Planned Behavior (TPB) menjadi salah satu teori yang mendukung tindakan whistleblowing. Teori ini menjadi teori yang baik untuk mengukur persepsi sikap individu terhadap tindakan whistleblowing.

\section{Teori Perilaku Prososial (Prosocial Behavior Theory)}

Manusia itu dilahirkan sebagai makhluk sosial yang tidak bisa hidup tanpa bantuan dari orang lain, maka dari itu munculah perilaku prososial di kehidupan bermasyarakat. Perilaku prososial mencakup setiap tindakan untuk membantu orang lain, terlepas dari motif dari si penolong tersebut. Cropanzano dan Mictchell (2005) menjelaskan bahwa dasar teori pertukaran sosial adalah hubungan yang meningkat dari waktu ke waktu menjadi hubungan yang saling mempercayai, loyal, dan saling berkomitmen selama kedua belah pihak menaati aturan-aturan pertukaran.

Peraturan mengenai pertukaran umumnya melibatkan hubungan timbal balik 
atau aturan membayar kembali dalam bentuk tindakan dari suatu pihak sebagai respon dari tindakan pihak lain (Cropanzano dan Mictchell, 2005). Pedekatan pertukaran sosial mengintegrasikan keyakinan karyawan tentang bagaimana mereka diperlakukan oleh organisasinya dan bagaimana organisasi berkomitmen kepada mereka. Dengan demikian, jika karyawan percaya bahwa organisasi berkomitmen kepadanya maka karyawan juga akan berkomitmen kepada organisasi.

\section{Teori Kerja Iklim Etis (Ethical Climate Work Theory)}

Ethical climate work theory merupakan teori yang dikembangkan oleh Victor dan Cullen (1988) sebagai pengembangan teori moral kognitif. Terdapat dua dimensi dari teori ini, yaitu an ethical approach dimension dan an ethical referent dimension. Dimensi pertama dari ethical climate work theory terdiri dari tiga pendekatan, yaitu egoism, benelovolence, dan principle. Organisasi dengan karakteristik egoism akan cenderung mempertimbangkan keuntungan pribadi ketika dihadapkan pada dilema etis. Organisasi dengan tipe benevolence akan cenderung mempertimbangkan kesejahteraan orang lain. Organisasi dengan tipe principle akan cenderung mempertimbangkan hal-hal yang berkaitan dengan peraturan dan hukum. Dimensi kedua ethical climate work theory terdiri dari: individual, lokal, dan cosmopolitan. Pada lokus analisis individual dasar pengambilan keputusan dalam dilemma etis adalah moral individu. Lokus analisis lokal didasarkan pada ekspektasi yang dating dari organisasi seperti kode etik dalam organisasi. Lokus analisis cosmopolitan didasarkan dari luar individu dan organisasi, seperti kode etik yang dikeluarkan oleh asosiasi profesional yang menaungi organisasi tersebut.

\section{Analisis Meta}

Analisis meta merupakan salah satu bentuk penelitian, dengan menggunakan data penelitian-penelitian lain yang telah ada (data sekunder). Oleh karena itu analisis meta merupakan metode penelitian kuantiatif dengan cara menganalisis data kuantitatif dari hasil penelitian sebelumnya untuk menerima atau menolak hipotesis yang diajukan dalam penelitian-penelitian tersebut. Analisis meta perlu dilakukan karena adanya realitas bahwa tidak ada penelitian yang terbebas dari kesalahan dalam penelitian meskipun peneliti telah berusaha meminimalisir kesalahan atau eror dalam penelitan tersebut. Untuk itu perlu dilakukan koreksi terhadap ketidaksempurnaan penelitian atau yang disebut dengan artefak (Hunter \& Schmidt, 2004).

Analisis meta mengumpulkan penelitianpenelitian dengan topik-topik yang relevan. Dalam analisis meta, data diolah dan digunakan untuk membuat kesimpulan secara statistik. Data tersebut dapat dinyatakan dengan berbagai ukuran yang dihitung atau dicari terlebih dahulu dengan formula yang disebut sebagai effect size. Effect size adalah indeks kuantitatif yang digunakan untuk merangkum hasil studi dalam analisis meta. Artinya, effect size mencerminkan besarnya hubungan antar variabel dalam masing-masing studi. Pilihan indeks effect size bergantung pada jenis data yang digunakan dalam studi.

\section{PENGEMBANGAN HIPOTESIS}

Semakin tinggi intensitas moral yang dirasakan dari suatu masalah, semakin besar kemungkinan orang tersebut untuk membuat keputusan etis, yang pada gilirannya memengaruhi niat untuk melakukan whistleblowing.

H1: Ethical judgment whistleblowing berpengaruh positif terhadap niat individu melakukan whistleblowing.

Seseorang yang memiliki locus of control cenderung mengandalkan persepsi dari dirinya sendiri atas jawaban benar atau salah, serta cenderung menerima konsekuensi dari perilakunya. Jika individu memiliki locus of control yang lebih tinggi, maka individu akan bersedia menerima risiko atau konsekuensi yang mungkin merugikan dirinya.

H2: Locus of control berpengaruh positif terhadap niat individu melakukan whistleblowing.

Karyawan akan menunjukan sikap dan perilaku positif, memiliki semangat untuk mempertahankan organisasinya, berusaha untuk meningkatkan prestasi, dan memiliki keyakinan yang kuat untuk mewujudkan tujuan organisasi (Kuryanto, 2011 dalam Hanjani et al, 2019). 
H3: Organizational commitment berpengaruh positif terhadap niat individu melakukan whistleblowing.

Jika kecurangan tidak terlalu serius, kemungkinan anggota organisasi lain tidak akan mendukung whistleblower untuk mengungkap fakta. Hal tersebut dikarenakan manfaat yang diterima tidak sebanding dengan biaya yang dikeluarkan oleh whistleblower (Miceli dan Near, 1985 dalam Natawibawa et al, 2019).

H4: Fraud severity rate berpengaruh positif terhadap niat individu melakukan whistleblowing.

Seseorang yang mengalami kemungkinan pembalasan yang lebih rendah akan meningkatkan kemungkinan untuk melaporkan kecurangan, sedangkan semakin tinggi kemungkinan pembalasan terhadap whistleblower, maka semakin rendah kemungkinan untuk melaporkan kecurangan (Kuncara et al., 2017 dalam Putriana et al., 2018).

H5: Personal cost berpengaruh negatif terhadap niat individu melakukan whistleblowing.

Memiliki personal responsibility atau tanggung jawab pribadi berarti menerima standar yang sudah ditetapkan masyarakat untuk perilaku individu. Apabila yang dilakukan individu tersebut tidak sesuai dengan standar yang ditetapkan, maka individu tersebut akan menyalahkan diri sendiri karena itu merupakan tanggung jawab pribadi dan menganggap bahwa dirinya telah gagal.

H6: Personal responsibility berpengaruh positif terhadap niat individu melakukan whistleblowing.

Karyawan yang puas dengan pekerjaan, lingkungan kerja dan gaji mereka, cenderung memiliki rasa untuk melindungi pekerjaan mereka serta citra organisasi mereka (Cecelia, 2013 dalam Said et al, 2017). Individu yang kurang puas terhadap pekerjaan mereka akan cenderung melakukan whistleblowing sebagai ekspresi pemberontakan terhadap organisasi.

H7: Job satisfaction berpengaruh negatif terhadap niat individu melakukan whistleblowing.
Perlakuan yang adil akan membuat karyawan merasa nyaman untuk berbicara dengan manajemen mengenai masalah yang bertentangan dengan tujuan organisasi.

H8: Fair treatment berpengaruh positif terhadap niat individu melakukan whistleblowing

Lingkungan kerja yang kooperatif dan fleksibel akan mengurangi tingkat stres dan meningkatkan kepuasan terhadap pekerjaan. Selain itu, budaya kerja sama akan memberikan dampak pada karyawan untuk lebih bersedia berdiskusi dengan manajemen mengenai kecurangan yang dilakukan oleh rekan-rekan mereka (Rothwell \& Baldwin, 2007 dalam Said et al, 2017).

H9: Cooperativeness berpengaruh positif terhadap niat individu melakukan whistleblowing.

Secara moral, tindakan whistleblowing layak untuk dilakukan karena melindungi pihak-pihak lain yang terkena dampak dari tindakan tidak etis organisasi. Sehingga, semakin tinggi moral yang dimiliki individu, maka semakin tinggi kemungkinan individu melakukan whistleblowing.

H10: Moral reasoning berpengaruh positif terhadap niat individu melakukan whistleblowing.

Adanya saluran pelaporan anonim akan berdampak bagi para pelapor kecurangan karena tidak perlu menggunakan identitas asli sehingga akan merasa aman dari upaya pembalasan dendam.

H11: Anonymous reporting channel berpengaruh positif terhadap niat individu untuk melakukan whistleblowing.

Proses pembelajaran akan memengaruhi individu untuk berperilaku sesuai dengan apa yang telah mereka amati, demikian juga whistleblowing. Karyawan tidak mungkin melaporkan tindakan kecurangan ketika mereka tidak memiliki pengetahuan yang cukup tentang whistleblowing.

H12: Education on Whistleblowing berpengaruh positif terhadap niat individu untuk melakukan whistleblowing. 
Ketika individu menganggap bahwa whistleblowing hanya akan berdampak buruk pada dirinya, maka ia akan cenderung tidak melakukan whistleblowing. Sebaliknya, ketika seorang individu menilai whistleblowing adalah hal yang positif baginya, maka dia akan cenderung melakukan whistleblowing.

H13: Attitude berpengaruh positif terhadap niat individu untuk melakukan whistleblowing.

Ketika ada sumber daya dan peluang yang mendukung seperti dukungan dari manajemen puncak atau saluran tepercaya, maka karyawan akan melakukan whistleblowing akan meningkat.

H14: Perceived behavioral control berpengaruh positif terhadap niat individu untuk melakukan whistleblowing.

Menurut CEVM dalam Farooqi et al. (2017), nilai dukungan organisasi menandakan sejauh mana suatu organisasi mendukung perilaku etis karyawannya. Oleh karena itu, karyawan akan mencoba melakukan tindakan etis seperti whistleblowing untuk melihat dukungan dari organisasi yang diterimanya.

H15: Organizational support berpengaruh positif terhadap niat individu untuk melakukan whistleblowing.

Ketika individu berpikir bahwa melaporkan kecurangan adalah perilaku yang dapat diterima atau perilaku yang diharapkan, maka mereka akan menerima konsekuensi dan lebih cenderung melakukan whistleblowing.

H16: Subjective norms berpengaruh positif terhadap niat individu untuk melakukan whistleblowing.

Individu yang memiliki komitmen profesional yang kuat akan berusaha menjalankan tugasnya secara professional. Apabila terjadi kecurangan dalam suatu organisasi, individu yang memiliki komitmen profesional yang kuat akan segera melaporkan kecurangan tersebut agar dapat menjalankan tugasnya secara profesional.

H17: Professional commitment berpengaruh positif terhadap niat individu untuk melakukan whistleblowing.

Menurut Cullen et al (2003) dalam Lestari dan Yaya (2017) anggota organisasi dengan karakter egoism akan memandang bahwa organisasi mengizinkan mereka untuk memaksimalkan kepentingan pribadi, sehingga selama tindakan whistleblowing tidak berdampak baik kepada individu, mereka cenderung tidak akan melaksanakannya.

H18: Ethical-climate egoism berpengaruh negatif terhadap niat individu untuk melakukan whistleblowing.

Ethical climate-benevolence mengacu pada perilaku pengambilan keputusan yang berdampak baik pada semua orang. Mereka akan menentang suatu kondisi yang tidak etis dengan memerhatikan pihak lain yang melanggar ketentuan dari organisasi tersebut.

H19: Ethical-climate benevolence berpengaruh positif terhadap niat individu untuk melakukan whistleblowing.

Anggota organisasi akan mempertimbangkan kebijakan di dalam organisasi dan peraturan yang menaungi organisasi tersebut untuk memutuskan etis tidaknya suatu tindakan. Berdasarkan hal tersebut, mereka akan mengambil keputusan yang salah satunya adalah melaksanakan tindakan whistleblowing.

H20: Ethical-climate principle berpengaruh positif terhadap niat individu untuk melakukan whistleblowing.

Anggota organisasi perlu diberikan sosialisasi untuk memahami ketentuan dan peraturan yang berlaku di organisasi serta pentingnya whistleblowing. Sehingga hal tersebut akan meningkatkan kesadaran anggota organisasi untuk melakukan whistleblowing secara sukarela.

H21: Sosialisasi antisipatif berpengaruh positif terhadap niat individu untuk melakukan whistleblowing.

Individu akan merasionalisasi tetap diam berdasarkan biaya pribadi seperti ketakutan akan pembalasan. Namun, ketika individu merasa memiliki kepentingan pribadi dalam tindak kecurangan, maka kemungkinan besar mereka akan melakukan whistleblowing.

H22: Self-Interest berpengaruh positif terhadap niat individu untuk melakukan whistleblowing.

Kemarahan akan memicu bias untuk melihat diri sendiri sebagai orang yang mampu dan 
berkuasa, sehingga ketika individu merasa marah mereka akan merasa berani melakukan whistleblowing.

H23: Feel anger berpengaruh positif terhadap niat individu untuk melakukan whistleblowing.

Setiap suku bangsa memiliki kebudayaan yang berbeda dengan suku bangsa lain. Hasil penelitian Keenan (2007) dalam Ridho dan Rini (2016) menunjukan bahwa para manajer Amerika Serikat lebih mungkin melakukan whistleblowing dibandingkan dengan para manajer Cina.

H24: Ethnic berpengaruh terhadap niat individu untuk melakukan whistleblowing.

Menjadi whistleblower merupakan tindakan yang berisiko karena terdapat ancaman fisik dan psikis baik secara langsung maupun tidak langsung dari pihak tertentu. Hal ini mempengaruhi keputusan individu untuk melakukan atau tidak melakukan whistleblowing. Apabila individu memiliki selfefficacy yang tinggi maka individu akan memiliki keyakinan pada diri sendiri untuk melakukan whistleblowing, begitu juga sebaliknya.

H25: Self-efficacy berpengaruh positif terhadap niat individu untuk melakukan whistleblowing.

Status manajerial menggambarkan sejauh mana individu dapat mengurangi tingkat kecurangan tergantung pada tingkat kekuasaannya. Keenan (2002) dalam Bernawati dan Napitupulu (2018) menemukan bahwa manajer level tinggi memiliki persepsi positif terhadap whistleblowing dan lebih cenderung melakukan whistleblowing.

H26: Managerial status berpengaruh positif terhadap niat individu untuk melakukan whistleblowing.

Pengambilan keputusan etis terjadi ketika seseorang menegosiasikan dilema etika yang dialami. Proses ini dipengaruhi oleh berbagai paradigma atau standar etika yang mengacu pada situasi yang terjadi. Sehingga, semakin tinggi tingkat pengambilan keputusan etis maka individu akan lebih terlibat dalam perilaku etis yaitu whistleblowing.
H27: Ethical decision making (EDM) berpengaruh positif terhadap niat individu untuk melakukan whistleblowing.

Apabila individu menerima reward saat melakukan whistleblowing, maka individu akan merasa dihargai dan terdukung. Hal tersebut akan meningkatkan intensitas individu untuk melakukan whistleblowing. Semakin sering seorang karyawan menerima reward atas whistleblowing yang dilakukan maka semakin besar pula kemungkinan karyawan tersebut mengulangi tindakan whistleblowing.

H28: Reward berpengaruh positif terhadap niat individu untuk melakukan whistleblowing.

Organisasi yang memiliki etika bisnis tinggi akan mengedepankan nilai-nilai etika, sehingga memberikan kenyamanan dan keamanan bagi whistleblower. Sebaliknya, apabila organisasi memiliki etika bisnis rendah, maka individu akan ragu untuk melakukan whistleblowing karena organisasinya tidak mengedepankan nilai-nilai etika.

H29: Corporate ethical berpengaruh positif terhadap niat individu untuk melakukan whistleblowing.

Schminke et al (2003) dalam Bernawati dan Napitupulu (2018) mengemukakan bahwa terdapat perbedaan antara pria dan wanita dalam hal etika, keyakinan, nilai, dan perilaku. Sehingga, perbedaan tersebut akan mempengaruhi niat individu untuk melakukan whistleblowing.

H30: Gender berpengaruh terhadap niat individu untuk melakukan whistleblowing.

Menurut Ahmad et al. (2012) dalam Natawibawa et al (2018) ketika situasi tidak berada di bawah kendali orang tersebut, maka tidak akan mempengaruhi keputusannya untuk melakukan whistleblowing atau tidak. Sehingga, individu yang memiliki controllability tinggi akan cenderung yakin bahwa mereka memiliki kendali dan mempengaruhi keputusannya untuk melakukan whistleblowing.

H31: Controllability berpengaruh positif terhadap niat individu untuk melakukan whistleblowing 


\section{Efek Moderasi}

Dalam penelitian ini penulis akan menganalisis efek moderasi. Efek moderasi penelitian ini disebabkan oleh perbedaan pengukuran untuk whistleblowing intention yang digunakan dari masing-masing sampel. Oleh karena itu, penulis mengajukan hipotesis sebagai berikut.

H32: Hubungan antara EJW dan niat individu untuk melakukan whistleblowing dimoderasi oleh model pengukuran whistleblowing intention.

H33: Hubungan antara LoC dan niat individu untuk melakukan whistleblowing dimoderasi oleh model pengukuran whistleblowing intention.

H34: Hubungan antara OC dan niat individu untuk melakukan whistleblowing dimoderasi oleh model pengukuran whistleblowing intention.

H35: Hubungan antara FSR dan niat individu untuk melakukan whistleblowing dimoderasi oleh model pengukuran whistleblowing intention.

H36: Hubungan antara PCR dan niat individu untuk melakukan whistleblowing dimoderasi oleh model pengukuran whistleblowing intention.

H37: Hubungan antara PRR dan niat individu untuk melakukan whistleblowing dimoderasi oleh model pengukuran whistleblowing intention.

H38: Hubungan antara FAIR dan niat individu untuk melakukan whistleblowing dimoderasi oleh model pengukuran whistleblowing intention.

H39: Hubungan antara MORAL dan niat individu untuk melakukan whistleblowing dimoderasi oleh model pengukuran whistleblowing intention.

H40: Hubungan antara ATD dan niat individu untuk melakukan whistleblowing dimoderasi oleh model pengukuran whistleblowing intention.
H41: Hubungan antara PBC dan niat individu untuk melakukan whistleblowing dimoderasi oleh model pengukuran whistleblowing intention.

H42: Hubungan antara SN dan niat individu untuk melakukan whistleblowing dimoderasi oleh model pengukuran whistleblowing intention.

H43: Hubungan antara PC dan niat individu untuk melakukan whistleblowing dimoderasi oleh model pengukuran whistleblowing intention.

H44: Hubungan antara ECE dan niat individu untuk melakukan whistleblowing dimoderasi oleh model pengukuran whistleblowing intention.

H45: Hubungan antara ECB dan niat individu untuk melakukan whistleblowing dimoderasi oleh model pengukuran whistleblowing intention.

H46: Hubungan antara ECP dan niat individu untuk melakukan whistleblowing dimoderasi oleh model pengukuran whistleblowing intention.

H47: Hubungan antara SA dan niat individu untuk melakukan whistleblowing dimoderasi oleh model pengukuran whistleblowing intention.

H48: Hubungan antara ETHNIC dan niat individu untuk melakukan whistleblowing dimoderasi oleh model pengukuran whistleblowing intention.

H49: Hubungan antara SELF dan niat individu untuk melakukan whistleblowing dimoderasi oleh model pengukuran whistleblowing intention.

H50: Hubungan antara REWARD dan niat individu untuk melakukan whistleblowing dimoderasi oleh model pengukuran whistleblowing intention.

H51: Hubungan antara GENDER dan niat individu untuk melakukan whistleblowing dimoderasi oleh model pengukuran whistleblowing intention.

Berdasarkan pembangunan hipotesis di atas, maka variabel yang digunakan yaitu: 


\begin{tabular}{|c|c|c|}
\hline & & Tabel 2. Deskripsi Variabel \\
\hline No & Variabel & Deskripsi \\
\hline 1 & Whistleblowing & $\begin{array}{l}\text { Pengukuran dengan (Likert Scale 1, Likert Scale 2, Likert Scale 3, Likert } \\
\text { Scale 4, Likert Scale 5, Semantic Differential Scale, Other) }\end{array}$ \\
\hline 2 & EJW & Ethical Judgement Whistleblowing \\
\hline 3 & LoC & Locus of Control \\
\hline 4 & $\mathrm{OC}$ & Organizational Commitment \\
\hline 5 & FSR & Fraud Severity Rate \\
\hline 6 & PCR & Personal Cost Reporting \\
\hline 7 & PRR & Personal Responsibility Reporting \\
\hline 8 & SATISFACTION & Job Satisfaction \\
\hline 9 & FAIR & Fair Treatment \\
\hline 10 & COOPERATIVE & Cooperativeness \\
\hline 11 & MORAL & Moral Reasoning \\
\hline 12 & ARC & Anonymous Reporting Channels \\
\hline 13 & EW & Education on Whistleblowing \\
\hline 14 & ATD & Attitude \\
\hline 15 & PBC & Perceived Behavioral Control \\
\hline 16 & OS & Organizational Support \\
\hline 17 & $\mathrm{SN}$ & Subjective Norms \\
\hline 18 & PC & Professional Commitment \\
\hline 19 & ECE & Ethical Climate-Egoism \\
\hline 20 & ECB & Ethical Climate-Benevolence \\
\hline 21 & ECP & Ethical Climate-Principle \\
\hline 22 & SA & Sosialisasi Antisipatif \\
\hline 23 & SI & Self-Interest \\
\hline 24 & ANGER & Feel Anger \\
\hline 25 & ETHNIC & Suku Bangsa \\
\hline 26 & SELF & Self-Efficacy \\
\hline 27 & STATUS & Managerial Status \\
\hline 28 & EDM & Ethical Decision Making \\
\hline 29 & REWARD & Reward \\
\hline 30 & CE & Corporate Ethical \\
\hline 31 & GENDER & Jenis Kelamin \\
\hline 32 & CONTROL & Controllability \\
\hline
\end{tabular}

Sumber: Data Olahan (2020)

Dengan deskripsi pengukuran sebagai berikut:

Tabel 3. Deskripsi Pengukuran

\begin{tabular}{cll} 
No & \multicolumn{1}{c}{ Pengukuran } & \multicolumn{1}{c}{ Deskripsi } \\
\hline 1 & Likert Scale 1 & Likert Scale 1-4 \\
2 & Likert Scale 2 & Likert Scale 1-5 \\
3 & Likert Scale 3 & Likert Scale 1-6 \\
4 & Likert Scale 4 & Likert Scale 1-7 \\
5 & Likert Scale 5 & Likert Scale \\
6 & Semantic Differential Scale & Skala Semantik Diferensial \\
7 & Other & Pengukuran Lainnya \\
\hline
\end{tabular}

Sumber: Data Olahan (2020)

\section{METODE}

Penelitian ini menggunakan metode analisis meta yang merupakan penelitian kuantitatif, dengan cara menganalisis hasil penelitian terdahulu dalam rentang 10 tahun terakhir yaitu 2010-2020 untuk memperoleh satu kesimpulan yang akurat. Data yang digunakan dalam penelitian ini adalah jurnal penelitian tentang whistleblowing intention yang dipublikasikan melalui media internet (google scholar, google, website resmi penerbit jurnal, dan lain-lain). Dari banyaknya penelusuran yang telah dilakukan, diperoleh 35 jurnal penelitian tentang whistleblowing 
intention yang memenuhi kriteria. Hasil perolehan atas penelusuran 35 jurnal tersebut menghasilkan 14 jurnal bahasa Inggris dan 21 jurnal bahasa Indonesia, seperti yang ditunjukan pada Tabel 4.
Tabel 4. Jumlah Data Penelitian

\begin{tabular}{lc}
\multicolumn{1}{c}{ Keterangan } & Jumlah \\
Jurnal Bahasa Inggris & 14 \\
Jurnal Bahasa Indonesia & 21 \\
\hline Total & 35 \\
\hline Sumber: Data Olahan (2020) &
\end{tabular}

\section{Formula dan Prosedur untuk Mengkonversi Studi Statistik ke $\mathbf{R}$}

Penelitian ini menggunakan $r$ sehingga statistik yang digunakan di dalam penelitian terdahulu dikonversikan ke dalam $r$ dengan pedoman sebagai berikut:

Tabel 5. Formula dan Prosedur

\begin{tabular}{|c|c|c|}
\hline $\begin{array}{l}\text { Statistik yang } \\
\text { akan dikonversi }\end{array}$ & Formula konversi kedalam r & Keterangan \\
\hline P Value & $\begin{array}{l}\text { 1. Konversi two tailed menjadi } \\
\text { one tailed } \\
\text { 2. Lihat nilai z dalam kondisi } \\
\text { profitabilitas normal }\end{array}$ & Nilai $p$ value dikalikan 2 , lihat tabel $z$ \\
\hline Statistik Z & $r=\sqrt{\frac{z^{2}}{N}}$ & \\
\hline Statistik t & $r=\sqrt{\frac{t^{2}}{t^{2}-d f}}$ & $\begin{array}{l}\text { Dapat digunakan dengan baik untuk paired atau } \\
\text { umpaired t test }\end{array}$ \\
\hline Statistik $\mathrm{f}$ & $r=\sqrt{\frac{F}{F+d f(e)}}$ & Hanya digunakan untuk one way ANOVA \\
\hline $\begin{array}{l}\text { Means and standar } \\
\text { deviations }\end{array}$ & $\begin{array}{l}r=\sqrt{\frac{\boldsymbol{x}^{\mathbf{z}}}{\boldsymbol{N}}} \\
d=\frac{\boldsymbol{x}_{\bullet}-\mathbf{x}_{\boldsymbol{c}}}{\mathbf{s}_{\mathbf{p}}}\end{array}$ & $\begin{array}{l}\mathrm{n}=\text { sample size, digunakan hanya saat } \mathrm{df}=1 \\
\mathrm{Xe}=\text { experimental group mean } \\
\mathrm{X} \mathrm{c}=\text { control group mean } \\
\mathrm{S} \mathrm{p}=\text { pooled (within subject) standar deviation }\end{array}$ \\
\hline
\end{tabular}

\section{Tahapan Analisis Meta}

Setiap studi mungkin melaporkan hasil analisisnya dalam hasil statistik yang berbedabeda seperti $p$-value, statistik $\mathrm{Z}$, statistik t, statistik F, mean dan standar deviasi. Oleh karena itu, dalam menentukan effect size seluruh hasil statistik harus terlebih dahulu dikonversi menjadi korelasi rata-rata $(r)$. Setelah melakukan konversi hasil statistik, selanjutnya adalah mengakumulasi effect size dan menghitung average correlation coefficient $(\bar{r})$.

Dalam menghitung average correlation coefficient $(\bar{r})$ dibutuhkan beberapa tahapan, yang pertama menghitung dengan rumus berikut:

$$
\overline{\mathbf{r}}=\frac{\sum\left(N_{I} r_{i}\right)}{\sum \mathbf{N}_{i}}
$$

Dimana $S_{p}^{2}$ adalah korelasi pada penelitian i dan adalah sample size pada penelitian i.
Selanjutnya, menghitung observed variance menggunakan rumus berikut:

$$
S_{r}^{2}=\frac{\sum N_{i}\left(r_{i-} \mathbf{r}\right)^{2}}{\sum N_{i}}
$$

Yang terakhir adalah menghitung estimasi sampling error variance dan menghitung variansi populasi dengan rumus berikut:

$$
\begin{array}{r}
S_{e}^{2}=\frac{\left(1-\overline{\mathrm{r}}^{2}\right)^{2} K}{\sum N_{i}} \ldots \ldots \ldots \ldots \ldots \ldots \ldots \ldots \ldots \ldots \ldots \ldots \ldots \\
S_{p}^{2}=S_{r}^{2}-S_{e}^{2}
\end{array}
$$

Dimana $S_{p}^{2}$ adalah variansi populasi yang sesungguhnya dan adalah total variansi yang diamati.

\section{Analisis Variabel Moderasi}

Setelah melakukan prosedur analisis meta, akan dilakukan analisis variabel moderasi untuk mengetahui jika terdapat kondisi dimana 
ada faktor lain mempengaruhi niat individu melakukan whistleblowing pada kondisi tertentu. Variabel moderasi adalah variabel yang bersifat memperkuat atau memperlemah pengaruh variabel independen terhadap variabel dependen. Dalam meta analisis, analisis variabel moderasi ini disebut juga sebagai analisis subgrup. Analisis subgrup dilakukan jika pada model teridentifikasi adanya heterogenitas.

Apabila hasil uji chi-square hitung lebih kecil dari chi-square tabel maka mengindikasikan bahwa tidak terdapat variabel moderasi. Sebaliknya, apabila hasil uji chisquare hitung lebih besar dari chi-square tabel maka mengindikasikan bahwa terdapat variabel moderasi. Lalu, jika hasil uji chi-square menghasilkan nilai yang tidak signifikan, hal ini memberi indikasi tidak ada variabel moderasi sehingga dapat disimpulkan bahwa perbedaan antara korelasi yang ada (hubungan antara berbagai faktor yang mempengaruhi variabel) adalah kesalahan statistik dan bukan kesalahan fungsi dari beberapa variabel moderasi. Sebaliknya jika uji chi-square menghasilkan nilai yang signifikan, berarti terjadi heterogenitas sehingga diperlukan memasukan variabel moderasi. Artinya, variasi hasil-hasil penelitian yang ada dimoderasi oleh variabel lain.

Pada penelitian ini, akan digunakan pengujian Chi-square dalam menentukan apakah terdapat variabel moderasi, dengan rumus sebagai berikut:

$$
X_{k-1}^{2}=\frac{N}{\left(1-\bar{r}^{2}\right)} S_{r}^{2}
$$

Dimana $\mathrm{k}$ adalah jumlah variabel dependen dan independen. Hipotesis analisis variabel moderator diuji dengan membandingkan hasil analisis meta subgroup, jika hasilnya tidak konsisten maka hipotesis bahwa variabel moderator memoderasi hubungan antara variabel independen dengan variabel dependen didukung Sebaliknya jika hasilnya konsisten maka hipotesis bahwa variabel moderator memoderasi hubungan antara variabel independen dengan varibel dependen ditolak atau tidak didukung.

\section{Pengujian Hipotesis}

Penelitian ini akan menganalisis hubungan antara masing-masing variabel independen terhadap variabel dependen. Interpretasi signifikansi dan penerimaan/penolakan hipotesis harus menggunakan interval kepercayaan, dalam hal ini penelitian faktor-faktor yang mempengaruhi niat individu untuk melakukan whistleblowing menentukan interval kepercayaan sebesar 95\% dengan formula $z$-statistic sebagai berikut:

$$
[\bar{r}-\mathrm{Z} \mathrm{0.975}, \overline{\boldsymbol{r}}+\mathrm{Z} \mathrm{0.975}] \approx[\bar{r}-(1.96), \overline{r+}
$$$$
\text { (1.96)] }
$$

Berdasarkan persamaan diatas maka dapat disimpulkan bahwa hubungan yang signifikan dapat ditunjukan dengan nilai ratarata korelasi $\bar{r}$ yang berada di antara nilai interval kepercayaan, yang mempunyai nilai positif atau negatif yang sama pada keduanya. Jika terdapat kondisi dimana salah satu nilai positif dan lainnya negatif maka kita dapat mengatakan bahwa korelasi rata-rata tidak signifikan. Koefisien nilai rata-rata korelasi $\bar{r}$ menunjukan arah hipotesis, sehingga dapat digunakan untuk membuktikan hipotesis directional (hipotesis yang menyatakan sifat dan arah hubungan). Apabila koefesien korelasi rata rata sesuai dengan arah hipotesis maka hipotesis diterima. Namun, jika sebaliknya hipotesis harus ditolak.

\section{Uji Sensitivitas}

Uji sensitivitas perlu dilakukan untuk membuktikan apakah terdapat efek moderasi dari status publikasi pada hubungan antara niat individu untuk melakukan whistleblowing dengan variabel explanatory. Uji sensitivitas dalam meta analisis dapat dilakukan dengan 3 (tiga) cara, yaitu sebagai berikut.

1) Melakukan perbandingan hasil apabila dianalisis menggunakan fixed effect model dengan hasil yang dianalisis dengan random effect model.

2) Menilai peran kualitas metodologi penelitian terhadap hasil yang diperoleh.

3) Mengidentifikasi adanya publication bias.

Dalam penelitian ini uji sensitivitas dilakukan dengan cara mengidentifkasi adanya publication bias. Pengujian ini dilakukan dengan cara subgroup atas variabel explanatory untuk status publikasi jurnal dan konferensi. Kondisi dimana efek moderasi terdapat bias apabila menunjukan perbedaan atas hasil subgroup antara status publikasi jurnal dan konferensi. Sebaliknya hasil penelitian akan menunjukan bahwa tidak terdapat bias apabila 
status publikasi variabel explanatory konsisten dengan hasil dari general analysis.

\section{HASIL DAN PEMBAHASAN}

Penelitian analisis meta ini menguji secara empiris faktor-faktor apa saja yang mempengaruhi niat individu untuk melakukan whistleblowing. Atas keseluruhan sampel penelitian diperoleh variabel independen sebanyak tiga puluh satu (31) variabel dengan tujuh (7) jenis kategori pengukuran whistleblowing intention, yaitu Likert Scale 1, Likert Scale 2, Likert Scale 3, Likert Scale 4, Likert Scale 5, Semantic Differential Scale dan Other. Berikut ini adalah ringkasan hasil pengujian yang telah dilakukan. Tabel atas hasil pengujian tidak dapat dilampirkan atas keterbatasan halaman, namun tersedia jika dibutuhkan.

Tabel 6. Ringkasan Hasil Pengujian Hipotesis

\begin{tabular}{|c|c|c|c|}
\hline No & & Variable Explanatory & $\begin{array}{c}\text { Hipotesis } \\
\text { (Terima/Tolak) }\end{array}$ \\
\hline 1 & EJW & Ethical Judgement Whistleblowing & Terima \\
\hline 2 & LoC & Locus of Control & Terima \\
\hline 3 & OC & Organizational Commitment & Terima \\
\hline 4 & FSR & Fraud Severity Rate & Terima \\
\hline 5 & PCR & Personal Cost Reporting & Tolak \\
\hline 6 & PRR & Personal Responsibility Reporting & Terima \\
\hline 7 & SATISFACTION & Job Satisfaction & Terima \\
\hline 8 & FAIR & Fair Treatment & Terima \\
\hline 9 & COOPERATIVE & Cooperativeness & Terima \\
\hline 10 & MORAL & Moral Reasoning & Terima \\
\hline 11 & ARC & Anonym Reporting Channels & Terima \\
\hline 12 & EW & Education on Whistleblowing & Terima \\
\hline 13 & ATD & Attitude & Terima \\
\hline 14 & PBC & Perceived Behavioral Control & Terima \\
\hline 15 & OS & Organizational Support & Terima \\
\hline 16 & SN & Subjective Norms & Terima \\
\hline 17 & PC & Profesional Commitment & Terima \\
\hline 18 & ECE & Ethical Climate-Egoism & Tolak \\
\hline 19 & ECB & Ethical Climate-Benevolence & Tolak \\
\hline 20 & ECP & Ethical Climate-Principle & Terima \\
\hline 21 & SA & Sosialisasi Antisipatif & Terima \\
\hline 22 & SI & Self-Interest & Tolak \\
\hline 23 & ANGER & Feel Anger & Terima \\
\hline 24 & ETHNIC & Suku Bangsa & Terima \\
\hline 25 & SELF & Self-Efficacy & Terima \\
\hline 26 & STATUS & Managerial Status & Terima \\
\hline 27 & EDM & Ethical Decision Making & Terima \\
\hline 28 & REWARD & Reward & Terima \\
\hline 29 & $\mathrm{CE}$ & Corporate Ethical & Terima \\
\hline 30 & GENDER & Jenis Kelamin & Terima \\
\hline 31 & CONTROL & Controllability & Terima \\
\hline
\end{tabular}


Berdasarkan tabel 6 pengujian efek moderasi terdapat 31 hipotesis yang tidak termasuk hipotesis moderasi, namun hanya 27 hipotesis yang diterima. Hipotesis yang ditolak disebabkan karena tidak signifikan yaitu variabel PCR dan ECB, dan sisanya karena memiliki arah yang berbeda dengan hipotesis yaitu ECE.

\section{SIMPULAN DAN SARAN}

\section{Simpulan}

Penelitian ini memuat 31 variabel independen dari 35 artikel sampel yang diperoleh dari berbagai jurnal internasional maupun nasional, konferensi, dan seminar dalam rentang waktu penelitian 10 tahun (20102020). Sampel yang diperoleh adalah sampel yang menunjukkan hubungan berbagai variabel terhadap niat individu untuk melakukan whistleblowing. Berdasarkan hasil penelitian menunjukan bahwa terdapat 28 variabel explanatory yang dapat menjadi faktor yang mempengaruhi niat individu untuk melakukan whistleblowing. Hasil pengujian sensitivitas menunjukan bahwa terdapat bias status publikasi pada variabel PCR dan ECB. Adanya bias pada status publikasi dapat disebabkan oleh hasil penelitian terbaru, bias reviewer atas penerimaan artikel menjadi jurnal ataupun perspektif penulis yang ingin memberikan kesan menarik kepada pembaca.

Terdapat 3 indikator yang digunakan penulis untuk menetapkan 5 variabel dominan yang dapat digunakan untuk mengukur niat whistleblowing. Yang pertama adalah variabel yang paling banyak digunakan pada sampel jurnal, kemudian variabel yang tidak memiliki bias publikasi, dan yang terakhir adalah variabel yang menunjukan hasil signifikan. Berdasarkan indikator tersebut dapat disimpulkan 5 variabel dominan tersebut adalah OC, FSR, ATD, PC, dan SN.

\section{Saran}

Penelitian ini memiliki beberapa keterbatasan yang dapat menjadi pentimbangan untuk penelitian selanjutnya yaitu:

1. Beberapa variabel explanatory tidak memenuhi kriteria untuk pengujian heterogenitas karena jumlah studi yang terbatas, sehingga subgroup atas variabel tersebut tidak dapat dilakukan.
2. Penelitian terdahulu mengenai faktorfaktor yang mempengaruhi niat individu untuk melakukan whistleblowing dengan studi analisis meta belum ada, sehingga penulis membuat beberapa asumsi berdasarkan hasil.

3. Terdapat beberapa peneliti yang tidak menyajikan pengukuran variabel dependen secara lengkap dalam artikelnya.

Berdasarkan keterbatasan penelitian diatas, penulis menyarankan beberapa rekomendasi untuk penelitian selanjutnya yaitu:

1. Peneliti dapat menambah periode sampling jurnal dan memilih kriteria jurnal yang mampu mewakili pengujian subgroup pada masing-masing variabel explanatory.

2. Penambahan referensi atas studi analisis meta.

3. Peneliti dapat memilih kriteria jurnal yang menyajikan pengukuran setiap variabel secara lengkap dalam artikelnya.

\section{REFERENSI}

Ajzen, I. 1991. The Theory of Planned Behavior. Organizational Behavior and Human Decision Processes, 50(2): 179211.

Bernawati, Y., and Napitupulu, G. B. 2018. The Effect of Organizational, Individual, and Demographic Factors on the Whistleblowing Intention. Journal of Accounting and Strategic Finance, 1 (01): 1-12.

Brennan, N., and Kelly, J. 2007. A study of Whistleblowing among Trainee Auditors. The British Accounting Review, 39(1), 61-87.

Cropanzano, R., and Mitchell, M. S. 2005. Social Exchange Theory: An Interdisciplinary Review. Journal of Management, 31(6), 874-900.

Farooqi, S., Abid, G., and Ahmed, A. 2017. How Bad it is to be Good: Impact of Organizational Ethical Culture on Whistleblowing (The Ethical Partners). Arab Economic and Business Journal, 12(2), 69-80. 
Gaurina, N. M., Purnamawati, I. A., and Atmadja, A. T. 2017. Pengaruh Persepsi Karyawan Mengenai Perilaku Etis Dan Whistleblowing System Terhadap Pencegahan Fraud (Studi Kasus Pada Bali Hai Cruises). E-Journal S1 Ak Universitas Pendidikan Ganesha, 8(2), 1-10.

Hanjani, A., Purwanto, A., and Kusumadewi, R. K. A. 2019. The Impact of Ethical Judgment, Locus of Control, and Organizational Commitments to Whistleblowing. Journal of Auditing, Finance, And Forensic Accounting, 6(2), 97-104.

Hunter, J. E., and Schmidt, F. L. 2004. Methods of Meta-Analysis: Correcting Error and Bias in Research Findings. Thousand Oaks, CA: SAGE.

Lestari, R., and Yaya, R. 2017. Whistleblowing dan Faktor-Faktor yang Mempengaruhi Niat Melaksanakannya oleh Aparatur Sipil Negara. Jurnal Akuntansi, 21(3), 336-350.

Natawibawa, I. W., Irianto, G., and Roekhudin, R. 2018. Self-Efficacy and Controllability as Whistleblowing Intention Predictors of Financial Managers in Educational Institutions. Jurnal Tata Kelola \& Akuntabilitas Keuangan Negara, 4(2), 147-166.

Natawibawa, I. W. Y., Irianto, G., and Roekhudin, R. 2019. Whistleblowing Intention of Financial Keepers in Education Organization. Jurnal Aplikasi Manajemen, 17(2), 199-206.

Putriana, A., Hariadi, B., and Prihatiningtias, Y. W. 2018. Factors Affecting Intention on Whistleblowing: An Analysis on Moderated Model of Whistleblowing Channel. Jurnal Tata Kelola \& Akuntabilitas Keuangan Negara,4(2), 125-145.

Ridho, M. S., \& Rini, R. (2016). Pengaruh Komitmen Profesional, Locus of Control, Keseriusan Pelanggaran Dan Suku Bangsa Terhadap Intensi
Whistleblowing (Studi Empiris pada Pemerintahan Daerah DKI Jakarta). Jurnal Equity, 19(1), 38-52.

Said, J., Alam, M. M., Mohamed, D. I. B., and Rafidi, M. (2017). Does job satisfaction, fair treatment, and cooperativeness influence the whistleblowing practice in Malaysian Government linked companies? Asia-Pacific Journal of Business Administration, 9(3), 220-231.

Victor, B., and Cullen, J. B. 1988. The Organizational Bases of Ethical Work Climates. Administrative Science Quarterly, 33(1), 101. 
JRAK, Volume 16, No.2 Agustus 2020 
$\bar{\ldots}$ 